\title{
Detection of Bacterial Contamination and Antibiotic Resistance at Neonate Intensive Care Unit in Ibn Al-Atheer Teaching Hospital for Children
}

\author{
Sahira I.H. Al-Sanjary ${ }^{*}$, Fulla Q.M .S.Yhya ${ }^{2}$ \\ $\mathbf{1}^{*}, \mathbf{2}$ Department of Biology, College of Science, University of Mosul, Mosul, Iraq \\ E-mail: ${ }^{1 *}$ sahira.scp5@ student.uomosul.edu.iq, ${ }^{2}$ Maruser2000@ gmail.com
}

(Received December 11, 2020; Accepted January 27, 2021; Available online June 01, 2021)

DOI: 10.33899/edusj.2021.129017.1123, (c) 2021, College of Education for Pure Science, University of Mosul.

This is an open access article under the CC BY 4.0 license (http://creativecommons.org/licenses/by/4.0/).

\begin{abstract}
The study included the isolation and diagnosis of some Gram positive and Gram negative bacterial species from the Neonate Intensive Care Unit in Ibn Al-Atheer Teaching hospital for children from August 2019 to February 2020.A total of 90 swabs were obtained from various sites of the ICU from Ibn Al-Atheer hospital environment. The swabs were inoculated on culture media including blood agar, mannitol salt agar and MacConkey agar. The growth showed different bacterial colonies which had been tested for their morphological and biochemical characteristics. 80 pure isolates, 76 of them were Gram positive bacteria, and 4 isolates were Gram negative bacteria. The highest rate of bacterial contamination was found in the couch and the incubator sites. The most prevalent bacteria isolated from inanimate surfaces were Staphylococcus aureus, coagulase negative staphylococci, Bacillus spp. in addition to Diphtheroids, Lactobacillus spp. Streptococcus pneumoniae, Klebsiella pneumoniae, and E, coli. Antibiotic susceptibility testing for all isolates was performed using 8 types of commonly used antibiotics in NICU. Taken all together, Gram positive and Gram negative bacteria showed high resistance against streptomycin, erythromycin, and ampicillin respectively. Notably, resistance to ampicillin and gentamicin were commonly demonstrated to be given as the first line of treatment in NICUs.
\end{abstract}

Keywords: NICU, bacterial, contamination, drug resistance
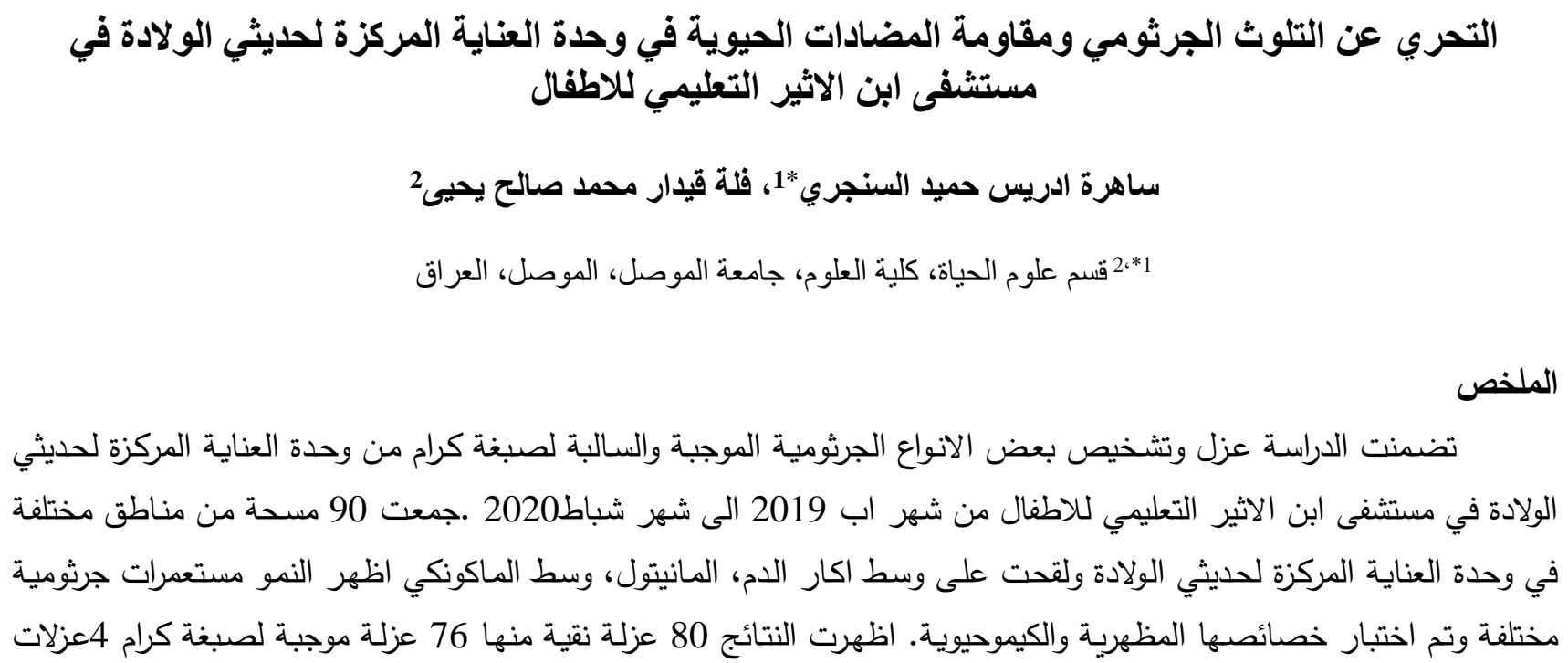
سالبة لصبغة كرام واظهرت النتائج ان اكثر العزلات تم تثخيصها في سرير الفحص والحاضنة والجراثيم المعزولة من الاسطح غير

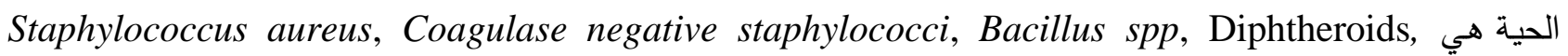
Lactobacillus spp, Streptococcus pneumoniae, Klebsiella pneumoniae, E. coli للمضادات الحيوية لجميع العزلات باستخدام 8 انواع من المضادات الحيوية الثائعة الاستخدام في العراق واظهرت الجراثيم الموجبة

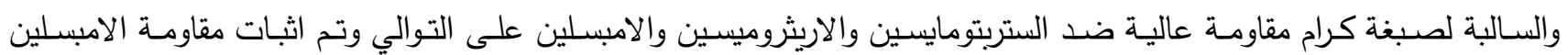
والجنتاميسين التي تعطى كخط علاجي اول في وحدة العناية المركزة لحديثي الولادة. الكلمات المفتاحية: وحدة العناية المركزة لحديثي الولادة ,الجراثيم، التلوث, مقاومة الادوية.

\section{Introduction}

NICU is a critical setting in which optimal effort is given for the survival of a high risk group of babies in severely ill conditions [1]. However, Intensive care unit (ICU)-acquired infections, specifically those caused by multidrug-resistant (MDR) bacteria, are the main cause of mortality and morbidity during or after hospital stays worldwide. Pathogens such as multi-drug resistant Gramnegative bacilli, Clostridium difficile, vancomycin-resistant enterococci (VRE) and methicillinresistant Staphylococcus aureus (MRSA), remain in the health care environment for days [2]. These pathogenic bacteria carry multi-drug resistance genes that may transfer a wide range of antimicrobial resistance and are usually disseminated by health care workers and patients by contaminating surfaces and elevating the risk of acquisition for other patients [3]. Repeated contamination of items, medical equipment, and other unrecognized reservoirs has been confirmed by environmental screening studies (4). If by any chance health care workers, come in contact with these contaminated surfaces during patient care they will increase the risk of transmission to others [4-5].

Several studies have already demonstrated the presence and persistence of bacterial nosocomial pathogens in hospital surfaces, like Enterococcus spp. Staph. aureus, Acinetobacter spp. E. coli, Klebsiella spp. Pseudomonas aeruginosa and Serratia marcescens [6-7], which may cause a range of nosocomial infections including urinary tract infections caused by Proteus spp. Pseudomonas spp. E. coli and Klebsiella spp. respiratory tract infections by streptoccoci, and septicemia which is caused by Staph. aureus and Staph. epidermidis [8].

Pneumonia and bloodstream infections are also common types of Hospital Acquired Infections (HAI) found in the NICUs in addition to meningitis, skin and soft tissue lesion, and conjunctivitis [9].

In appropriate antibiotic treatment or application of low concentrations of disinfectants for cleaning purposes in hospital environments will lead to the emergence of new bacterial strains that resist the commonly used antibiotics, Consequently, patients will require longer periods of hospital stay with additional treatment that may lead to serious side effects [10-11].

Immunocompromised infants, especially those who have undergone surgery or with congenital deformity, or low birth weight newborns, are at high risk for developing nosocomial infections (NI) and (HAI). Devices are part of the advances in medical therapy that have resulted in significant improvements in neonatal survival. On the other hand, it is well recognized that these same beneficial tools can also place the newborn at a considerable higher risk of health-care associated infections.In this series, the exposures to parenteral nutrition, percutaneous catheter, central venous catheter or mechanical ventilation independently increased the risk for neonatal Nis [12].

The underdeveloped innate immune defense of newborns, easily damaged skin, and their exposure to a variety of invasive devices and broad-spectrum antibiotics make them highly susceptible to infections. The defenses are even more critical in low birth weight and immature newborns[13]. 
Incompetent hand washing practices, and outbreaks with multi-drug resistant bacteria significantly promote the spread of pathogenic bacteria. Hence; installing sinks is of vital importance to facilitate hand washing [14-15]. Also too many infant patients and/or less staff members seem to aggravate the problem of cross-infection [16]. Understanding the sources and the routes of transmission of the infectious agents is one of the biggest difficulties in ruling NICU and HAI.

The aim of the current work is to identify bacterial contaminants from medical equipment and non-living surfaces in NICUs in Ibn Al-Atheer hospital and their antimicrobial susceptibility patterns.

\section{Materials and Methods}

Sample collection included surfaces such as the inside of incubators, couch, weighing scale, oxygen suction machines, and baby cots. Specimen were collected under aseptic techniques. Each swab sample was placed in a separate sterile labeled test tube and transported to the laboratory within one hour. Swabs were streaked on to blood, mannitol salt and MacConkey agar and incubated at 37 ${ }^{\circ} \mathrm{C}$ for 24 hrs. Bacterial isolates from culture-positive plates were identified by Gram staining, and biochemical characteristics. Antimicrobial susceptibility testing was performed using modified Kirby- Bauer disk diffusion according to the Clinical and Laboratory Standards Institute (CLSI), guidelines [17].

Bacterial isolates were tested for the following commonly used antibiotics: amoxicillinclavulanic acid (AMC, $30 \mu \mathrm{g}$ ), ampicillin (AMP, $10 \mu \mathrm{g}$ ), ciprofoxacin (CIP, $5 \mu \mathrm{g}$ ), gentamicin (GEN, $10 \mu \mathrm{g}$ ), erythromycin (E, $15 \mu \mathrm{g}$ ), cefotaxime (CTX, $30 \mu \mathrm{g})$, (HIMEDIA, Company).

\section{Results and Discussion}

A total of 80 bacterial isolates were obtained from 90 swab samples collected in the first part of the present study. It was observed that all items were contaminated, mostly with multispecies, especially couch, incubators, and weighing scale, which are mostly used and touched by the workers (Table1). Following the morphological and the biochemical characterization of 80 contaminant isolates Staph. aureus (33) followed by Coagulase Negative Staphylococci (CoNS) (17), Bacillus spp. (15), Lactobacillus spp. (5), S. pneumoniae (3), Diphtheroids (3) and Enterobacteria (4) were identified.

Table 1: Type of bacterial species isolated from inanimate surfaces in NICUs.

\begin{tabular}{|c|c|c|c|c|c|c|c|c|}
\hline & 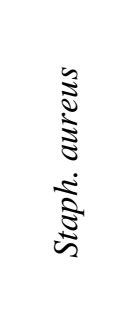 & $\begin{array}{l}\frac{n}{0} \\
\frac{0}{0} \\
\stackrel{0}{0} \\
\frac{0}{0} \\
\stackrel{0}{0}\end{array}$ & 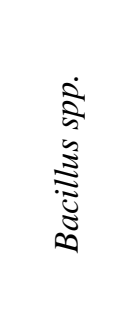 & 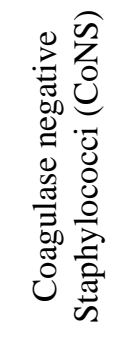 & 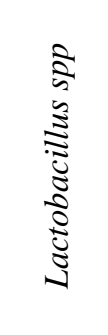 & 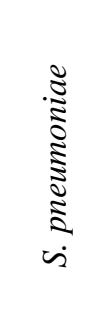 & 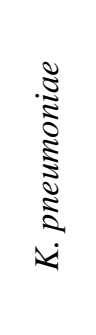 & 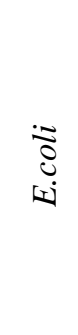 \\
\hline Couch & 22 & 3 & 9 & 3 & 5 & - & - & - \\
\hline Weighing scale & 1 & - & 4 & 2 & - & - & - & - \\
\hline Incubators & 3 & - & 1 & 2 & - & 3 & 2 & 2 \\
\hline Oxygen & - & - & 1 & - & - & - & - & - \\
\hline Baby cot & 7 & - & - & 5 & - & - & - & - \\
\hline \multirow[t]{2}{*}{$\begin{array}{l}\text { Suction } \\
\text { machine }\end{array}$} & - & - & - & 5 & - & - & - & - \\
\hline & $\begin{array}{c}(33) \\
(41.25)\end{array}$ & $\begin{array}{c}(3) \\
(3.75)\end{array}$ & $\begin{array}{c}(15) \\
(18.75) \\
\end{array}$ & $\begin{array}{c}(17) \\
(21.25) \\
\end{array}$ & $\begin{array}{c}(5) \\
(6.25) \\
\end{array}$ & $\begin{array}{c}(3) \\
(3.75) \\
\end{array}$ & $\begin{array}{c}(2) \\
(2.5) \\
\end{array}$ & $\begin{array}{c}(2) \\
(2.5) \\
\end{array}$ \\
\hline
\end{tabular}


Among medical equipment, the incubators and the open tables were notably contaminated with multispecies of Gram positive and Gram negative bacteria which are considered one of the contributing factors to HCAI due to the humid and warm environment that makes them easy to flourish nosocomial flora.

Members of the genera above are known to cause nosocomial infections in infants. These results are in accordance with many studies in that $S$. aureus remains to be a common causative agent of outbreaks and health-care-associated infections in neonatal intensive care units [18]. It is considered the second most common agent of late-onset sepsis, ventilator-associated pneumonia and bloodstream infections in NICU [19]. In addition to Staph. Aureus, the study also demonstrated the prevalence of Gram negative enterobacteria ( $E$. coli and $K$. pneumoniae ), CoNS and streptococci contaminants inside the incubator. Transmission of these genera by direct contact of contaminated equipment or indirectly via the hands of healthcare workers may cause neonatal sepsis which is a major cause of morbidity among neonates admitted at the NICU [20-22]. These pathogens can be directly transferred to the patients' skin. Among medical equipment, incubators in neonatal units have been shown to be a source of microorganisms potentially associated in the transfer of HAIs. An important virulence factor in these bacterial species is their ability of biofilm-production and high resistance to antibiotics, which may contribute as reservoirs of resistance genes [15, 23-24].

$B$. cereus and B. subtilis have become recognized as opportunistic human pathogens. Usually, most Bacillus spp. were known as environmental contaminants and seldom associated with diseases when isolated from patient samples [25]. Recently, the genus has been classified as an opportunistic pathogen that may cause severe infections in immunocompromised patients [26]. B. cereus has been implicated as the cause of HAI- bloodstream infections [27]. It is a spore forming bacteria that can contaminate linen and is able to survive ordinary washing and laundering processes [28]. Another study by Bentur et al., 2007 reported that Bacillus spp. could cause catheter infections in an immunocompromised child. Hence, the types of Bacillus spp. obtained from blood from central venous catheters should not be neglected or considered as contaminants [29]. Also, Ravine, 2019 reported that Bacillus spp. are a threat to immunocompromised patients [30].

Diphtheroids were also isolated in the current study and are commonly considered as contaminants from the skin in routine diagnostic methods. They are seldom identified to the species level. Previous research works have shown the biofilm producing activity of isolates from catheter and prostatic resulting in recurrent infections and antibiotic resistance [31-34]. These organisms can be seen upon Gram staining of clinical specimens showing abundance of pleomorphic Gram-positive rods or isolated as the pure species in culture. Their potential involvement in infection should be suspected as a possibility. Therefore, species-level identification of diphtheroids is essential to determine whether an isolate belongs to a species associated with specific types of infections [35].

Multidrug resistant (MDR) was defined as acquired non susceptibility to at least one agent in three or more antimicrobial categories. [36]. This study revealed worrying prevalence rates of resistance against many commonly used antibiotics, which limits the options for treatment (Table 2). 
Table (2): Antibiotic susceptibility profile of the bacterial isolates.

\begin{tabular}{|c|c|c|c|c|c|c|c|}
\hline Antibiotics & $\begin{array}{c}\text { Staph. } \\
\text { aureus } \\
n=33 \\
\mathrm{n} \mathrm{R}(\%)\end{array}$ & $\begin{array}{c}\text { CoNS } \\
n=17 \\
\mathrm{n} \mathrm{R}(\%)\end{array}$ & $\begin{array}{c}\text { Bacillus } \\
\text { spp. } \\
\mathrm{n}=15 \\
\mathrm{n} \mathrm{R}(\%)\end{array}$ & $\begin{array}{c}S . \\
\text { Pneumoniae } \\
n=3 \\
\mathrm{n} \mathrm{R}(\%) \\
\end{array}$ & $\begin{array}{c}K . \\
\text { Pneumonia } \\
n=2 \\
\mathrm{n}(\%)\end{array}$ & $\begin{array}{c}\text { E. coli } \\
n=2 \\
\mathrm{n}(\%)\end{array}$ & $\begin{array}{l}\text { Total }(\%) \\
\text { resistance }\end{array}$ \\
\hline Ampicillin & $28(84.8)$ & $12(70.5)$ & $10(66.6)$ & $3(100)$ & $2(100)$ & $2(100)$ & 71.25 \\
\hline Amoxicillin & $13(39.4)$ & $10(58.8)$ & $13(86.6)$ & $3(100)$ & $2(100)$ & $2(100)$ & 53.75 \\
\hline Gentamicin & $19(57.6)$ & $5(29.4)$ & $9(60)$ & $2(66.6)$ & $2(100)$ & $1(50)$ & 47.5 \\
\hline Streptomycin & $33(100)$ & $17(100)$ & $15(100)$ & $3(100)$ & $2(100)$ & $2(100)$ & 100 \\
\hline Ciprofloxacin & $8(24.2)$ & $3(17.6)$ & $3(20)$ & $1(33.3)$ & $1(50)$ & $1(50)$ & 21.25 \\
\hline Erythromycin & $33(100)$ & $11(64.7)$ & $15(100)$ & $3(100)$ & - & - & 77.5 \\
\hline Cefixime & $5(15.2)$ & $4(23.5)$ & $5(33.3)$ & $2(66.6)$ & $2(100)$ & $2(100)$ & 25 \\
\hline Cefotaxime & $7(21.2)$ & $2(11.7)$ & $8(58.3)$ & $1(33.3)$ & $1(50)$ & $2(100)$ & 26.25 \\
\hline
\end{tabular}

Among Gram positive bacteria; all Staph. aureus isolates were resistant to streptomycin, and erythromycin, CoNS staph were resistant to the broad spectrum antibiotic streptomycin, Bacillus spp. resisted streptomycin and erythromycin, and $S$. pneumoniae were resistant to ampicillin, amoxicillin, streptomycin and erythromycin. Gram negative bacterial isolates represented by K. pneumoniae and E. coli were also resistant to ampicillin, amoxicillin, streptomycin and cefotaxime ( resistant to more than three antimicrobial classes), hence they have been categorized as Multi Drug Resistant strains. Clinical isolates such members of Family Enterobacteriaceae, for example, E. coli, K. pneumoniae, and Proteus spp. rapidly develop antibiotic resistance and spread in the hospital environment [37]. These results agree with several studies showing high rate of resistance to ampicillin and amoxicillin, aminoglycosides, and various classes of cephalosporins [38-39]. A study in sub-Saharan Africa and Asia has revealed resistance of the two common pathogens Klebsiella spp. and Staph. aureus to all commonly used antibiotics in one study [40-41].

Other antibiotics like erythromycin shown rising resistance against Staph. aureus and streptococci species like S. pyogenes, and S. pneumoniae [42]. Also, in the present work, erythromycin resistance was highest against $S$. pneumoniae. More worrisome, is the rise of (ESBL) pathogens that leads to third generation cephalosporins resistance including cefotaxime [43]. E. coli and $K$. pneumoniae are most expected to acquire ESBLs, but these enzymes are also noted in other species [44]. Nevertheless, the results of the current study cannot be compared to others because it is well known that antimicrobial sensitivity patterns may vary in different geographical regions and can change over time.

Although many hi-tech methods have been developed, hand washing with soap and water or alcohol disinfection is still the most essential measure for personal hygiene and preventing HCAIs. But, because of the rise of antibiotic-resistant bacteria and ignorance of some HCWs to apply correct practice for infection control, Healthcare associated infections pursue to be one of the biggest causes of mortality all around the world. Therefore, it is essential to make strategic measures, awareness and hand washing procedures to overcome this conflict [45]. 


\section{Conclusion}

The rate of bacterial contamination in the (NICUs) in Ibn Al-Atheer Teaching Hospital for Children is high and showed resistance of antibiotics commonly used in Ibn Al-Atheer Hospital which are commonly given as the first line of treatment in NICUs

\section{Acknowledgments}

The authors wish to thanks the Neonate Intensive Care Unit in Ibn Al-Atheer Teaching Hospital for Children for their help to complete this work.

\section{References}

1- Bulmer J.L and Burgard N.A., "A practical guide to pediatric intensive care".3nd Ed. Philadelphia. Mosby yearbook 5:540-545. (1990).

2- Chia P., Sengupta S., Kukreja, A., Antimicrob Resist Infect Control.,9: 29. (2020).

3- Hanczvikkela A \& Tothb A. Journal of Infection and Public Health., 11: 801-806. (2018).

4- Lemmen S.W., Hafner H., Zolldan D., Stanzel S., Lutticken R. J. Hosp. Infect., 56:191- 197. (2004).

5- Bhalla A., Pultz N.J., Gries D.M., Ray A.J., Eckstein E.C., Aron D.C., Donskey C.J. Infect. Control Hosp. Epidemiol., 25:164-167. (2004).

6- Kramer A., Schwebke I., Kampf G., BMC Infectious Diseases., 6: 130. (2006).

7- de Abreu P.M., Farias P.G., Paiva G.S., Almeida A.M., Morais P.V., BMC Microbiol.,14:118. (2014).

8- Otter J. A. and French G. L., J. Clin. Microbiol., 47: 205-7. (2009).

9- Kumara S., Shankarb B., Aryaa S., Debc M., Chellani H. Journal of Infection and Public Health., $11: 275-279$. (2018).

10- Hotchkiss J. R., Holley P and Crooke P. S., J. Am. Soc. Nephrol., 2: 1176-85. (2007).

11- Dorchis F., NFS., 90-351. (2005).

12- Brady M.T., Am J Infect Control ;33:268-75. ( 2005).

13- Tavora A.C., Castro A.B., Militao M.A., Girao J.E., Ribeiro K.B., Tavora L., Braz J Infect Dis ;12:75 -79. (2008).

14- Pelke S., Ching D., Easa D., Melish M.E., Arch Pediatr Adolesc Med; 148: 1016-1020. ( 1994).

15- Haque K.N and Chagla A.H., J Hospital Infection., 14: 159-162. ( 1989).

16- Isaacs D and Moxon E.R"Handbook of Neonatal Infections" W.B Saunders, London.250-268. (1999).

17- Clinical and Laboratory Standards Institute. 36:26. CLSI. (2016)

18- Krawczenko W.S, Jankowska A and Kurylak A., Arch Med Sci 5: 854-858.( 2012).

19- Hornik C.P., Fort P., Clark R.H., Watt K., Benjamin D.K., Smith P.B.; Early Hum Dev.,88: S69S74. (2012).

20- Hocevar S.N., Edwards J.R., Horan T.C., Morrell G.C., Iwamoto M., Lessa F.C Infect Control Hosp Epidemiol., 33: 1200-1206. ( 2012).

21- Gastmeier P., Loui A., Stamm-Balderjahn S., Hansen S., Zuschneid I., Sohr D., Am J Infect Control.,35:172-176. (2007).

22-Peterside N., Pondei K and Felix O. Infect Control Hosp Epidemiol., 43: 183 - 190. (2015).

23-Vishal H., Marcel S., Wil H. F. G., Alewijn O., Ronald D. G., Peter W. M. H., and Rene F. K., J Clin Microbiol., 48: 3876-3881. (2010).

24-Oliveira F. and Cerca N. J Antibiot.,66: 739-741. (2013).

25-Jorgensen J.H., Pfaller M.A., Carroll K.C., Funke G, Landry M.L., Richter S.S., Warnock D.W"Manual of Clinical Microbiology". ${ }^{11 \text { th }}$ edn. ASM.106-120. (2015).

26-Cheng V.C.C., Chen J.H.K., Leung S.S.M., Wong S.C., Wong S.C.Y. Clin Infect Dis., 64: S91S97. (2017). 
27-Saito N, Kondo J, Haruki S. J Infect Chemother., 22:96-101. ( 2016).

28-Hosein I.K, Hoffman P.N, Ellam S., J Hosp Infect., 85:149-54. ( 2013).

29-Bentur H., Dalzell A and Riordan F. Ann Clin Microbiol Antimicrob.,6: 12. (2007).

30- Funke G, Bernard K.A., "Manual of Clinical Microbiology". 9 Ed. Washington D.C. ASM.485514. (2007).

31-Funke G., Topley and Wilson's." Microbiology and Microbial Infections, Bacteriology". 10 Ed. Washington. ASM.977-997. (2010).

32- Bernard K., J Clin Microbiol.,50:3152-58. (2012).

33-De Pascale G., Montini L., Pennisi M.A., Bernini V., Maviglia R., Bello G., Crit Care.,18: 90. (2014).

34-Kwaszewska A.K., Brewczyńska A., Szewczyk E.M., Pol J Microbiol.,55 : 189 - 93. (2006).

35-Leal S.M., Jones M., Gilligan P.H., J Clin Microbiol.,54:2928-2936. (2016).

36-Basak S., Singh P., Rajurkar M., J. Pathog., 4:1-5. (2016).

37-Arias C.A and Murray B. E. The New England Journal of Medicine.,360:439-443. (2009).

38- Rahman S., Hameed A., Roghani M.T.and Ullah Z., Arch Dis Child Fetal Neonatal.,87: 52-4. (2002).

39-Uhammad Z., Ahmed A., Hayat U., Wazir M.S., Rafiyatulla H., Waqas H. J Ayub Med Coll Abbottabad.,22:33-6. (2010).

40-Sivanandan S., Soraisham A.S., Swarnam K. Int J Pediatr.1-9. (2011).

41- Mohsen M., Ramy N., Saied D., Akmal D., Salama N., Abdel Haleim M.M and Aly H.A.,ntimicrobial Resistance \& Infection Control., 6: 61-63. (2017).

42-Desjardins M., Delgaty K.L., Ramotar K., Seetaram K., Toye B., J Clin Microbiol;42:5620-3. (2004).

43-Gupta A., Della-Latta P., Todd B. Infect Control Hosp Epidemiol., 25:210-215. (2004).

44-Livermore D M. , Journal of Internal Medicine., 27: 128-142. (2012).

45-Mirsoleymani S.R., Salimi M., Brojeni M.S., Ranjbar M. and Mehtarpoor M- International Journal of Pediatrics, vol. 2014, Article ID 126142, 6 pages. (2014). 